\title{
Bringing Language and Philosophy Together through Linguistic and Philosophical Interpretation of Language Units
}

\author{
Ruzana Pskhu \\ Russian Peoples' Friendship University \\ Moscow, Russia \\ r.pskhu@mail.ru
}

\author{
Galina Zashchitina \\ Moscow State Linguistic University \\ Moscow, Russia \\ jackdawnest@gmail.com
}

\author{
Irina Kholina \\ Moscow State Linguistic University, \\ Moscow, Russia \\ kholina007@rambler.ru
}

\begin{abstract}
The article presents an attempt to analyze the way by which such linguistic units as 'philosophy' and 'poetry' can reveal a shared philosophical potential in certain contexts which may be down to the similarity of semes. The authors resort to such means as componential and philosophicalhermeneutic methods of investigation to unravel the philosophical potential of the English language highlighting the fact that such methods and the results are by themselves a valuable means for Philosophy, Linguistics, Culture and Literature students to draw on.
\end{abstract}

Keywords-philosophy; language; semantics; poetry; meaning

\section{INTRODUCTION}

In the dialogue "Fedrus" (245a) Plato defines poetry as a type of the sacred madness - along with the prophetic ecstasy. Democritus, according to Horace, supposes, "Helicon is closed for the poets who have common sense". Kierkegaard defines the religious stage of the development of a person as elimination of the objective criteria of morality, the objective goodness and the objective evil, in other words as a specific madness. Could it be that the religious poetry is a double madness? By no means. Mary Midgley (born in 1919), the contemporary British philosopher, for example, assumes that our vision - the ways of representation of the world - determines the direction of our thoughts, and is the source of our poetry, which exists only for the expression of this vision in a concentrated form. In other words, whatever we are talking about, physics or lyrics, we always talk about a good poetry or a bad poetry. Strangely, Midgley applies the term 'poetry' as a full philosophical term. It would be interesting to look into the philosophical potential of the word 'poetry'. To do that, first of all, we should define the basic tasks of the research, which are:
- Analysis of the semantic structure of the word 'poetry' and 'philosophy' (based on the authoritative English dictionaries and encyclopedias).

- Analysis of the contextual meaning of the word 'poetry' (based on the British National Corpus)

- Analysis of the contextual philosophical meaning of the word 'poetry' (based on Mary Midgley's work "Science and Poetry")

The most appropriate method of investigation seems to be componential and philosophical-hermeneutic methods of investigation.

As an anticipated scientific result, we expect to prove the idea that some ordinary words of the English language have semantic potential to create philosophical terms through a specific linguistic and philosophical interpretation, which is revealed by the context they are used in, as significance of context to the interpretation of words arouses no doubt [1].

The List of Sources includes the most authoritative encyclopedias and dictionaries, such as:

- The New Encyclopedia Britannica in 30 Volumes. Printed in U.S.A.: William Benton, Publisher, 1975. vol.14.

- The Encyclopedia Americana. International Edition. In 30 Volumes. Printed in U.S.A.: Americana Corporation, 1973. vol.22.

- The Encyclopedia of Religion. ed. by Mircea Eliade. Printed in U.S.A.: Simon \& Schuster Macmillan, 1995. Vol. 11\&12.

- ENCARTA World English Dictionary. London: Bloomsbury Publishing Plc. 1999. 
- The Oxford English Dictionary. 2-d edition. Prepared by J.A. Simpson and E.S.C. Weiner. Oxford: Claredon Press, 1989.

- A New English Dictionary on Historical Principles. Ed. by James A.H. Murray, Henry Bradley, William A. Craigie, C.T. Onions. Oxford: Oxford Press, 1933.

- A New English Dictionary on Historical Principles. Ed. by Sir James A.H. Murray. Oxford: Oxford Press, 1909.

- Webster's New International Dictionary of the English Language. 2-d edition, Printed in U.S.A., 1947.

- The New lexicon Webster's Dictionary of the English Language. New York: Lexicon Publications, INC, 1990.

- Merriam Webster Dictionary (http://www.merriamwebster.com/dictionary

- Cambridge International Dictionary of English London, 1995

- The Encyclopedia of philosophy. Ed. by Paul Edwards. In 8 volumes. Printed in U.S.A.: Simon \& Schuster Macmillan, 1996.

- Routledge Encyclopedia of Philosophy. In 10 volumes. Ed. by Edward Craic. London and New York: T J International Ltd. 1998.

- Encyclopedia of Religion and Ethics. Ed. By J. Hastings. Edinburgh, 1908-1921.

- Longman. Dictionary of Contemporary English. New edition. For advanced learners. UK, 2009.

- Funk \& Wagnalls. New "Standard" Dictionary of the English Language. New York: Funk \& Wagnalls Company, 1962.

- Webster's New Twentieth Century Dictionary of the English Language. 2-d edition, Cleveland and New York: The world publishing company, 1963.

- Webster's New International Dictionary of the English Language. 2-d edition, Printed in U.S.A.: C.\&C. Merriam Company, 1955.

- The Random House Dictionary of the English Language. New York: Random House, 1966.

- The New Oxford Thesaurus of English. Ed. by Patrick Hanks. Oxford: Oxford University Press, 2000

- MacMillan Open Dictionary (http://www.macmillandictionary.com/)

- Longman English Dictionary Online (http://www.ldoceonline.com)

- Longman New Universal Dictionary, England, 1982
- Webster's New Twentieth Century Dictionary Unabridged, USA, 1978

\section{LANGUAGE UNITS IN THE MIRROR OF COMPONENTAL ANALYSIS}

As a result of the study of the sources mentioned above we can assume there can be two types of the word "poetry" definition:

The linguistic definition, which includes the following two features:

i. The art of writing poems

ii. The other way of using language (versification)

And the encyclopedic definition, which includes the next two features:

i. A quality of beauty, gracefulness and a deep feeling.

ii. A mode of thought

The particular semantic analysis of the word 'poetry' and the relevant semes to the word 'philosophy' demonstrate the following results.

- Based on MacMillan Open Dictionary www.macmillandictionary.com

Poetry

1) Poems

2) Poems as a subject in schools and universities

3) Someone or something of great beauty, emotion or imagination or the quality of beauty, emotion or imagination

\section{$\downarrow$ \\ Imagination}

1) The ability to think of clever and original ideas, possibilities or solutions

1.1. The ability to form a picture, story or idea in your mind

1.2. The ability to think, feel or believe something that is not real or true

2) A feeling of interest and excitement about something

$$
\downarrow
$$

Philosophy

1) The study of theories about the meaning of things such as life, knowledge and beliefs; a system of theories developed by someone as a result of the study of philosophy.

2) A system of beliefs that influences someone's decisions and behavior; a belief or attitude that someone uses for dealing with life in general. 
Theory

1) One or more ideas that explain how or why something happens

2) The set of general principles that a particular subject is based on

3) An idea that you believe is true although you have no proof

\section{$\downarrow$ \\ Idea}

We can see here that the common seme for both words is the word 'idea'.

- Based on Longman English Dictionary Online (www.ldoceonline.com)

\section{Poetry}

1) Poems in general, or the art of writing them

2) A quality of beauty, gracefulness, and deep feeling

\section{Feeling}

1) An emotion that you feel, such as anger, sadness, or happiness

2) Way somebody thinks/feels

3) Opinion

4) To think that something is probably true, or will probably happen

5) General attitude

6) Something that you feel in your body, such as heat, cold, tiredness etc.

7) Ability to feel

8) Emotions not thought,

$$
\text { etc. }
$$

\section{Opinion}

Philosophy

1) The study of the nature and meaning of existence, truth, good and evil, etc.

2) The views of a particular philosopher or group of philosophers

3) The attitude or set of ideas that guides the behavior of a person or organization.

\section{$\downarrow$ \\ View}

1) Opinion, what you think or believe about something (= opinion)
2) Way of considering, a way of thinking about or understanding something

3) Sight; What you are able to see or whether you can see it

4) Scenery, the whole area that you can see from somewhere, especially when it is very beautiful or expressive, etc.

\section{$\downarrow$ \\ Opinion}

We can see here that the common seme for both words is the word 'opinion'.

- Based on Merriam Webster Dictionary (www.merriam-webster.com/dictionary)

Poetry

1) Metrical writing - verse; the productions of a poet poems

2) Writing that formulates a concentrated imaginative awareness of experience in language chosen and arranged to create a specific emotional response through meaning, sound, and rhythm

3) Something likened to poetry especially in beauty of expression; poetic quality or aspect

\section{Meaning}

Philosophy

1) The study of ideas about knowledge, truth, the nature and meaning of life

2) A particular set of ideas about knowledge, truth, the nature and meaning of life, etc.

3) A set of ideas about how to do something or how to live

\section{Meaning}

We can see here that the common seme for both words is the word 'meaning'.

- Based on Cambridge International Dictionary of English, London, 1995

\section{Poetry}

1) Poems in general as a form of literature

2) If something has poetry, it is very beautiful or expressing

\section{$\downarrow$}

Literature

1) Written artistic works, particularly those with a high and lasting artistic value

2) All the texts relating to a subject, particularly those written by specialists 
3) Printed material published by a company which is intended to encourage people to buy that company's products or services

4) Material that an organization publishes in order to persuade people to agree with its opinions.

$$
\begin{gathered}
\downarrow \\
\text { Value }
\end{gathered}
$$

Philosophy

1) The use of reason in understanding such things as the nature of reality and existence, the use and limits of knowledge and the principles that govern and influence moral judgments

2) A group of theories and ideas related to the understanding of that subject

3) A particular system of beliefs, values and principles

4) An approach to life and their way of dealing with it

$$
\begin{gathered}
\downarrow \\
\text { Value }
\end{gathered}
$$

We can see here that the common seme for both words is the word 'value'.

- Based on Longman New Universal Dictionary, England, 1982

\section{Poetry}

1) Metrical writing; verse; a poet's compositions; poems

2) Writing that is arranged to formulate a concentrated imaginative awareness of experience through meaning, sound and rhythm

3) A quality of beauty, grace and great feeling

Awareness

realization, perception or knowledge; consciousness

$$
\downarrow
$$

Knowledge

Philosophy

1) The pursuit of wisdom; the study of the nature of knowledge and existence and the principles of moral and aesthetic value

2) The philosophical principles or teachings of a specified individual, group or period

3) The sum of beliefs and attitudes of a specified individual, group or period; equanimity in the face of trouble or stress

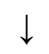

Knowledge
We can see here that the common seme for both words is the word 'knowledge'.

- $\quad$ Based on Webster's New Twentieth Century Dictionary Unabridged, USA, 1978

$\underline{\text { Poetry }}$

1) Writing of poems

2) Poems; poetical works

3) Something like poetry in quality or emotional effect

4) Poetic quality or spirit

\section{$\downarrow$ \\ Spirit}

1) The life principle; the soul

2) The thinking, motivating, feeling part of man; mind; intelligence

3) Life, will, consciousness, thought etc., regarded as separate from matter

4) A supernatural being (as a ghost, demon, angel etc.)

5) An individual person or personality thought of as showing or having some specific qualities

6) Frame of mind; disposition; mood; temper

7) Vivacity, courage, vigor, enthusiasm etc.

8) Enthusiastic loyalty

9) Real meaning; true intention

10) A pervading animating principle, essential or characteristic quality or prevailing tendency or attitude

11) A divine animating influence or inspiration

12) A strong alcoholic liquor produced by distillation

etc.

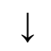

Principle

Philosophy

1) Originally, love of wisdom or knowledge

2) A study of the processes governing thought and conduct; theory or investigation of the principles or laws that regulate the universe and underlie all knowledge and reality; included in the study are aesthetics, ethics, logic, metaphysics etc.

3) The general principles or laws of a field of knowledge, activity

4) A particular system of principles for the conduct of life, a treatise covering such a system; a study of human morals, character, and behavior; mental balance believed to result from this; calmness; composure 
$\downarrow$

\section{Metaphysics}

1) The branch of philosophy that deals with the first principles and seeks to explain the nature of being or reality (ontology) and of the origin and structure of the world (cosmology): it is closely associated with a theory of knowledge (epistemology)

2) Speculative philosophy in general

3) The theory of principles (of some branch of knowledge)

4) Popularity, any very subtle, perplexing, or difficult reasoning

5) Occult lore (archaic)

\section{Principle}

We can see here that the common seme for both words is the word 'principle'.

Now let us see what the most frequent meanings are when it comes to the way the word 'poetry' is presented in the National British Corpus. Having investigated about 200 passages we selected the most popular fragments, such as:

H8V 838: But in fact they stopped well short of this principle, because they believed that the peculiar organization of meaning in poetry led back in the end to the 'real' world.

H8V 821: The chief property of poetry is coherence, not of a logical kind, but consisting in the harmonization of conflicting meanings or attitudes; poetry is objectively characterized, Wimsatt suggested, by a 'wholeness of meaning established through internally differentiated form, the reconciliation of diverse parts".

H8V 833: Wimsatt and Brooks, on the other hand, approached the question of meaning from a more mentalistic point of view, and for this reason were able to argue that poetry related to knowledge rather than emotions, while still accepting that its function was not, like that of ordinary discourse, to point directly to things. Etc.

Then it will be of interest to dwell upon Mary Midgley's understanding of the word 'poetry'. She uses this word in the next meanings:

Poetry is a concentrated form of world-vision, expressed directly and immediately [2].

Poetry supplies the language in which our imaginative visions are most immediately articulated [3].

Poetry is a power of generating forceful visions and crucial ideas, which makes possible their later articulation by the intellect [3].

\section{CONCLUSION}

Judging by the results of our investigation we can say that the study of the semantic structure of the words "poetry" and "philosophy" showed that the potential semes in the semantics of the word "poetry" are also present in the meaning of the word "philosophy", but in their latent form, which could be actualized or explicated in the context. In other words, Mary Midgley's texts fix the development of a new philosophical term "poetry" and there seem to be semantic potentialities for that inherent in the English literary language. The results may also be looked upon in terms of the evident educational potential as both Philosophy students and students majoring in Linguistics and other Humanitarian subjects may benefit from such an approach in interpreting language units both in isolation and in discourse.

\section{REFERENCES}

[1] Allan Keith. Linguistic Meaning. London: Routledge and Kegan Paul. 1986.

[2] M. Midgley. Science and Poetry. London and New-York: Routledge, 2001, p.2, passim.

[3] M. Midgley. Science and Poetry, p. 51-52 